\title{
Development of a generic approach to native metalloproteomics: application to the quantitative identification of soluble copper proteins in Escherichia coli
}

\author{
Ana-Maria Sevcenco - Gerard C. Krijger • \\ Martijn W. H. Pinkse · Peter D. E. M. Verhaert • \\ Wilfred R. Hagen · Peter-Leon Hagedoorn
}

Received: 18 November 2008 / Accepted: 24 January 2009/Published online: 11 February 2009

(C) The Author(s) 2009. This article is published with open access at Springerlink.com

\begin{abstract}
A combination of techniques to separate and quantify the native proteins associated with a particular transition metal ion from a cellular system has been developed. The procedure involves four steps: (1) labeling of the target proteins with a suitable short-lived radioisotope (suitable isotopes are ${ }^{64} \mathrm{Cu},{ }^{67} \mathrm{Cu},{ }^{187} \mathrm{~W},{ }^{99} \mathrm{Mo},{ }^{69} \mathrm{Zn}$, ${ }^{56} \mathrm{Mn},{ }^{65} \mathrm{Ni}$ ); (2) separation of intact soluble holoproteins using native isoelectric focusing combined with blue native polyacrylamide gel electrophoresis into native-native $2 \mathrm{D}$ gel electrophoresis; (3) spot visualization and quantification using autoradiography; and (4) protein identification with tandem mass spectrometry. The method was applied to the identification of copper proteins from a soluble protein extract of wild-type Escherichia coli K12 using the
\end{abstract}

Electronic supplementary material The online version of this article (doi:10.1007/s00775-009-0477-9) contains supplementary material, which is available to authorized users.

\section{A.-M. Sevcenco · M. W. H. Pinkse · P. D. E. M. Verhaert}

W. R. Hagen · P.-L. Hagedoorn $(\bowtie)$

Department of Biotechnology,

Delft University of Technology,

Julianalaan 67, 2628 BC Delft,

The Netherlands

e-mail: p.1.hagedoorn@tudelft.nl

\section{A.-M. Sevcenco · G. C. Krijger}

Department of Radiation,

Radionuclides and Reactors,

Delft University of Technology,

Mekelweg 15, 2629 JB Delft,

The Netherlands

Present Address:

G. C. Krijger

RIKILT Institute of Food Safety,

Bornsesteeg 45, 6708 PD Wageningen,

The Netherlands radioisotope ${ }^{64} \mathrm{Cu}$. The E. coli protein $\mathrm{CueO}$, which has previously been only identified as a multicopper oxidase following homologous overexpression, was now directly detected as a copper protein against a wild-type background at an expression level of $0.007 \%$ of total soluble protein. The retention of the radioisotope by the copper proteins throughout the separation process corroborates the method to be genuinely native. The procedure developed here can be applied to cells of any origin, and to any metal having suitable radioisotopes. The finding that the periplasmic protein $\mathrm{CueO}$ is the only major form of soluble protein bound copper in E. coli strengthens the view that the bacterial periplasm contains only a few periplasmic copper proteins, and that the cytosol is devoid of copper proteins.

Keywords Metalloproteomics - Copper ·

Blue native polyacrylamide gel electrophoresis .

Multicopper oxidase - Radioisotope

$\begin{array}{ll}\text { Abbreviations } \\ \text { BN-PAGE } & \begin{array}{l}\text { Blue native polyacrylamide gel } \\ \text { electrophoresis }\end{array} \\ \text { CBB } & \begin{array}{l}\text { Coomassie brilliant blue } \\ \text { Chaps }\end{array} \\ & \begin{array}{l}\text { 3-[(3-Cholamidopropyl)dimethylammonio] } \\ \text { propanesulfonic acid }\end{array} \\ \text { DLU } & \text { Digital light units } \\ \text { ESI } & \text { Electrospray ionization } \\ \text { IPG } & \text { Immobilized pH gradient } \\ \text { ICP } & \text { Inductively coupled plasma } \\ \text { IEF } & \text { Isoelectric focusing } \\ \text { LB } & \text { Luria-Bertani } \\ \text { LC } & \text { Liquid chromatography } \\ \text { MS } & \text { Mass spectrometry } \\ \text { MS/MS } & \text { Tandem mass spectrometry }\end{array}$


OES Optical emission spectroscopy

PAGE Polyacrylamide gel electrophoresis

QTOF Quadrupole time of flight

SDS Sodium dodecyl sulfate

SOD Superoxide dismutase

TEMED $\quad N, N, N^{\prime}, N^{\prime}$-Tetramethylethylenediamine

Tris Tris(hydroxymethyl)aminomethane

\section{Introduction}

Approximately one third of all proteins are estimated to contain metal cofactors [1]. For example, copper is an essential transition metal in all aerobic organisms, e.g., in electron-transfer proteins, in terminal oxidases, and in superoxide detoxification. Nevertheless, high concentrations of copper are toxic. In Escherichia coli several systems keep the copper concentration within safe boundaries. CopA pumps out excess of copper from the cytoplasm, multicopper oxidase $\mathrm{CueO}$ oxidizes cuprous ions to the less toxic cupric ions, and the CusCFBA system is involved in the efflux of copper from the periplasm and the cytoplasm. Furthermore, a plasmid-encoded PcoABCDE system for copper homeostasis occurs in certain E. coli strains that experience high copper stress in their natural environment [2]. Additionally, E. coli contains the copper enzymes cytochrome $c$ oxidase Cyt bo3, NADH dehydrogenase $\mathrm{NDH}-2$, and aromatic amine oxidase MaoA. Finally, E. coli contains a copper- and zinc-containing superoxide dismutase (SOD; SodC) that functions next to a manganese SOD (SodA) and an iron SOD (SodB).

Recently it has been shown that the folding localization of proteins is a determinant in the incorporation of specific metal ions [3]. Copper was found to be incorporated into proteins that fold in the periplasm, while manganese was found in proteins that fold in the cytoplasm. This and previous research into the copper metabolism of $E$. coli has led to the view that most copper trafficking takes place in the periplasm, and that the cytosol is essentially devoid of copper and copper proteins [4].

In the present study we assessed the use of a "copperfilter" approach to the proteome of aerobically grown $E$. coli as an example to develop and validate a generic metalloproteomics method. For the separation of complex protein mixtures, a novel combination of techniques is evaluated to help in achieving this goal.

Polyacrylamide gel electrophoresis (PAGE) is a widely used analytical tool for separation and quantification of protein mixtures; however, it is commonly carried out under denaturing conditions. For metalloproteins this typically means that the bound metal is lost during the separation process. Schägger and von Jagow [5] have developed a nondenaturing technique called "blue native polyacrylamide gel electrophoresis" (BN-PAGE) which is based on the specific binding of Coomassie brilliant blue (CBB) G250 to proteins. CBB G250 provides the negative charges to the proteins without denaturing them (i.e., unlike sodium dodecyl sulfate, SDS). BN-PAGE has been adapted for several different applications [6-13]. The combination of BN-PAGE with SDS-PAGE as a second dimension was used to study mitochondrial and photosynthetic protein complexes. The 2D BN/BN-PAGE method was used to analyze the interaction between proteins within the respiratory chain complexes and subcomplexes [14-16]. However, the separated proteins in the 2D-PAGE are, again, in a denaturated state (BN/SDS-PAGE) or, when they are kept in a native state, their separation suffers from a very limited resolution (BN/BN-PAGE).

To separate proteins with 2D-PAGE in a native state and with high resolution we here evaluate a combination of native isoelectric focusing (IEF) in the first dimension and BN-PAGE in the second dimension. Radioisotopes were used to localize and quantify the target metalloproteins. In addition, the IEF provides the isoelectric point of the native separated proteins. In the present study on soluble coppercontaining proteins of wild-type E. coli $\mathrm{K} 12$, the method was validated and optimized using a model recombinant E. coli strain which overexpresses the soluble blue-copper protein azurin from Pseudomonas aeruginosa.

\section{Materials and methods}

\section{Bacterial strains}

Wild-type E. coli $\mathrm{K} 12$ and the recombinant strain E. coli JM101 pUC18-azu [17] were used. The strain with the plasmid carrying the structural gene for the blue-copper protein azurin from $P$. aeruginosa was a generous gift from Armand Tepper (Leiden University, The Netherlands). The bacterial growth was performed in $200 \mathrm{ml}$ Luria-Bertani (LB) medium in a 500-ml Erlenmeyer flask at $37^{\circ} \mathrm{C}$ overnight. The recombinant strain E. coli JM101 pUC18$a z u$ was grown in the presence of $500 \mu \mathrm{M}$ isopropylthiogalactoside and $70 \mu \mathrm{M}$ ampicillin. A volume of $2 \mathrm{ml}$ of the ${ }^{64} \mathrm{Cu}$ solution described in the following section was added to the medium at the start of the growth period.

Preparation of radioisotope solution

High-specific-activity ${ }^{64} \mathrm{Cu}\left(t_{1 / 2}=12.7 \mathrm{~h}\right)$ was prepared as described earlier [18]. In short, $50 \mathrm{mg}$ zinc oxide was irradiated with fast neutrons $\left(1.9 \times 10^{19} \mathrm{~m}^{-2} \mathrm{~s}^{-1}\right)$ at the Reactor Institute Delft (Delft, The Netherlands) for $12 \mathrm{~h}$. During this irradiation, ${ }^{64} \mathrm{Cu}$ was produced from ${ }^{64} \mathrm{Zn}$ by 
the nuclear exchange of a proton for a neutron. The separation of the copper from zinc was performed in an acidwashed glass column which contained packed resin (Dowex $2 \times 8,200-400$ mesh was purchased from Dow Chemical, Terneuzen, The Netherlands). The eluted ${ }^{64} \mathrm{Cu}$ was evaporated to dryness in a glass vial on a hot plate for $1 \mathrm{~h}$. After the glass vial had cooled down to room temperature, the radioisotope was dissolved in $5 \mathrm{ml} 1.0 \mathrm{mM}$ $\mathrm{HCl}$.

\section{Metal analysis}

The amount of total copper present in both the LB medium and the ${ }^{64} \mathrm{Cu}$ solution was quantified using a PerkinElmer 4300 dual view inductively coupled plasma (ICP) with optical emission spectroscopy (OES) spectrometer. Measurements were performed at three different wavelengths: 224,324 , and $327 \mathrm{~nm}$.

Protein sample preparation for native 2D-PAGE

The cells were spun down using a Jouan CR 4.11 centrifuge at $3,500 \mathrm{rpm}$ at $5{ }^{\circ} \mathrm{C}$ for $60 \mathrm{~min}$ and were resuspended in $1 \mathrm{ml} 50 \mathrm{mM}$ tris(hydroxymethyl)aminomethane (Tris)$\mathrm{HCl} \mathrm{pH} \mathrm{8.} \mathrm{The} \mathrm{cell} \mathrm{suspension} \mathrm{was} \mathrm{collected} \mathrm{in} \mathrm{a} \mathrm{2-ml}$ Eppendorf tube in which $0.5 \mathrm{~g}$ of glass beads $(106-\mu \mathrm{m}$ diameter) was present. To break down the polysaccharide walls of the cells, a volume of $20 \mu \mathrm{l} 10 \mathrm{mg} / \mathrm{ml}$ lysozyme was added to the Eppendorf tube. Native soluble protein extracts were obtained after vortexing with a home-made bead beater at $2,500 \mathrm{rpm}$ at $5{ }^{\circ} \mathrm{C}$ for $1 \mathrm{~h}$, and broken cells were spun down in an Eppendorf centrifuge at 14,000 rpm, $5{ }^{\circ} \mathrm{C}$ for $60 \mathrm{~min}$. Subsequently, $500 \mu \mathrm{l}$ of the extract was concentrated tenfold using a Microcon filter (Millipore) with $3-\mathrm{kDa}$ cutoff. The protein concentration was determined with the bicinchoninic acid method using a BC assay kit (Uptima-Interchim) according to the manufacturer's instructions.

\section{Native 2D-PAGE}

A schematic representation of the entire method is presented in Fig. 1. The first dimension of the native 2D-PAGE, native IEF, was performed using a Multiphor II flatbed electrophoresis system (GE Healthcare) at $15{ }^{\circ} \mathrm{C}$. Linear immobilized $\mathrm{pH}$ gradient (IPG) gel strips (linear $\mathrm{pH}$ $4-7,24 \mathrm{~cm}$ ) were rehydratated by placing each strip in a reswelling tray gel-side down in $350 \mu \mathrm{l}$ rehydratation solution and covered with DryStrip cover fluid for $12 \mathrm{~h}$. The rehydratation solution was composed of a 1:7 mixture of solution A (4\% 3-[(3-cholamidopropyl)dimethylammonio]propanesulfonic acid (Chaps), 0.5\% IPG buffer, $6.2 \mathrm{mg} / \mathrm{ml}$ 1,4-dithiothreitol) and solution B (2\% Chaps, $0.5 \%$ IPG buffer, $0.002 \%$ bromophenol blue). The protein

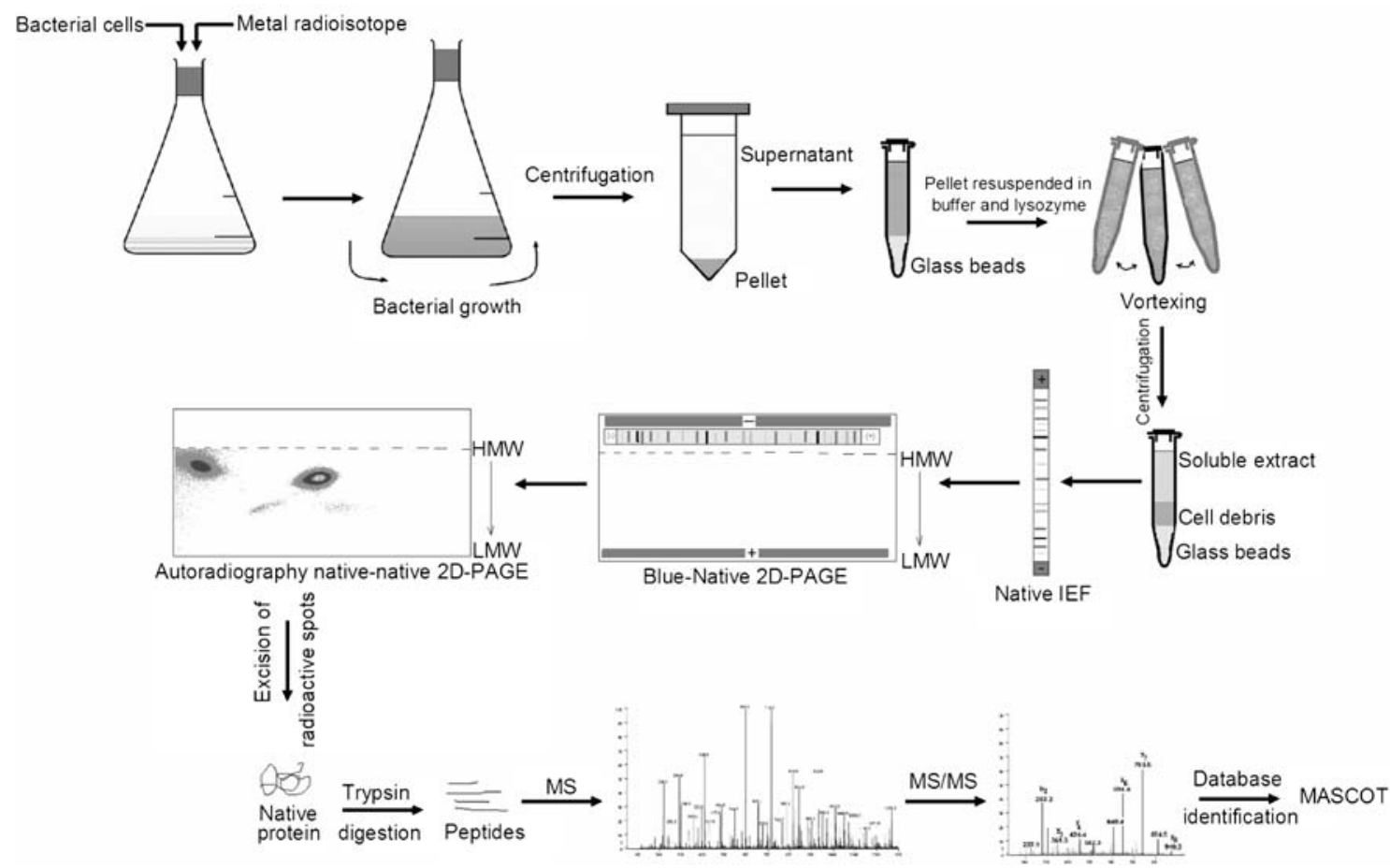

Fig. 1 Overview of the metalloproteomics procedure. $I E F$ isoelectric focusing, $P A G E$ polyacrylamide gel electrophoresis, $H M W$ high molecular weight, $L M W$ low molecular weight, $M S$ mass spectrometry 
sample was applied either by cup loading or by rehydration loading. When rehydratation loading was used, $50 \mu$ protein sample was added to the rehydratation solution before placement of the IPG strip. IEF of 500-1,500 $\mu \mathrm{g}$ protein sample was performed at $3,500 \mathrm{~V}$ for $12 \mathrm{~h}$ (continuously) after an initial $1 \mathrm{~min}$ at $500 \mathrm{~V}$ ramping up to $3,500 \mathrm{~V}$ in 90 min (gradient).

The second dimension, BN-PAGE, was also performed with the Multiphor II flatbed electrophoresis system, but at $5{ }^{\circ} \mathrm{C}$ on precast homogenous $12.5 \%$ gels (ExcelGel 2D, GE Healthcare). Native buffer strips for the ExcelGel 2D gels were not commercially available; therefore, they were prepared as follows. The anode strips $(134 \mathrm{ml})$ consisted of $30 \mathrm{ml} 1.8 \mathrm{M}$ Tris/HAc pH 6.6, $48 \mathrm{ml} 40 \%$ 37.5:1 acrylamide/bisacrylamide solution $(2.6 \% \mathrm{C}), 54 \mathrm{ml}$ Milli-Q water, $40 \mu \mathrm{l} N, N, N^{\prime}, N^{\prime}$-tetramethylethylenediamine (TEMED), and $2 \mathrm{ml} \mathrm{10 \%} \mathrm{ammonium} \mathrm{persulfate.} \mathrm{The} \mathrm{cathode}$ strips $(134 \mathrm{ml})$ consisted of $60 \mathrm{ml} 0.16 \mathrm{M}$ Tris/1.6 M $N$-tris[hydroxymethyl)methyl]glycine $\mathrm{pH} 7.1,48 \mathrm{ml} 40 \%$ $37.5: 1$ acrylamide/bisacrylamide solution $(2.6 \% \mathrm{C}), 24 \mathrm{ml}$ Milli-Q water, $0.0028 \mathrm{~g}$ CBB G 250 (Serva), $40 \mu \mathrm{l}$ TEMED, and $2 \mathrm{ml} \mathrm{10 \%} \mathrm{ammonium} \mathrm{persulfate.} \mathrm{Before} \mathrm{the}$ TEMED and ammonium persulfate were added, the monomer solutions were degassed for $10 \mathrm{~min}$. Immediately after ammonium persulfate and TEMED had been added, the monomer solution was poured into the casting devices for regular buffer strips (GE Healthcare). The acrylamide monomer solution was overlaid with 2-butanol and the polymerization took place for 3-4 h at room temperature. After polymerization, the strips could be stored at $5{ }^{\circ} \mathrm{C}$ for several weeks.

After the first-dimension separation, the IPG strips were equilibrated in $10 \mathrm{ml}$ solution containing $25.5 \%$ glycerol, $450 \mathrm{mM}$ aminocaproic acid, and $2 \mathrm{mg}$ CBB G 250 in $50 \mathrm{mM}$ Tris- $\mathrm{HCl} \mathrm{pH} 6.8$, for $15 \mathrm{~min}$ at $5{ }^{\circ} \mathrm{C}$. After $15-\mathrm{min}$ equilibration, the excess of the equilibration solution was removed by lightly tapping the IPG strip edgewise on filter paper. Subsequently, the IPG strip gel was placed upside down on the 2D-PAGE gel, parallel with the cathode strip with a distance of 3-5 mm between them. The BN-PAGE was run in two steps: $120 \mathrm{~V}$ for $1.5 \mathrm{~h}$ at $20 \mathrm{~mA}$ and $30 \mathrm{~W}$ followed by $600 \mathrm{~V}$ for $2.5 \mathrm{~h}$ at $30 \mathrm{~mA}$ and $30 \mathrm{~W}$. After the first step, the IPG strip was removed from the 2D-PAGE gel. Autoradiograms were taken from the IPG strips before and after the second dimension, and from the second dimension BN-PAGE gel. In each case the gels were placed between two plastic sheets and incubated at $-20{ }^{\circ} \mathrm{C}$ with a phosphor screen on top for $2 \mathrm{~h}$.

Autoradiography of the 2D-PAGE gels

${ }^{64} \mathrm{Cu}$ was quantified using a multipurpose phosphor screen $(12.5 \mathrm{~cm} \times 25.2 \mathrm{~cm})$, a phosphor screen reader model
Cyclone, and OptiQuant software all purchased from PerkinElmer. 3D images of selected parts of the 2D-PAGE gel were constructed in MATLAB 7.4 (The MathWorks) by importing data from a grid drawn over the target spots in OptiQuant software. After each use, the phosphor screen was blanked out using a transilluminator (Westburg, Stratagene). The phosphor screens were calibrated using a set of sample application papers (GE Healthcare) that contained $10 \mu \mathrm{l}$ of different concentrations $(1.4,7,14,70$, $140,700 \mathrm{nM})$ of the ${ }^{64} \mathrm{Cu}$ solution $(30 \mathrm{MBq} / \mathrm{ml})$. The papers were left to dry at room temperature for $30 \mathrm{~min}$. After the drying period, they were sealed between $50-\mu \mathrm{m}$ transparent polyethylene plastic sheets $(250 \mathrm{~mm} \times$ $350 \mathrm{~mm}$, MiniGrip) with a phosphor screen on top incubated for intervals of $2 \mathrm{~h}$. The phosphor screen was laserscanned immediately after 2-h exposure in the Cyclone phosphor imager at 600-dpi resolution. The intensity data obtained were expressed in digital light units (DLU). In parallel, the same volumes of ${ }^{64} \mathrm{Cu}$ standard solutions were measured in an automatic gamma counter (Wizard 1480-011; Wallac Turku, Finland), and corrected for counting efficiency, geometry, and decay time. The data obtained were expressed in becquerels. The calibration curve from the ${ }^{64} \mathrm{Cu}$ standard solutions was used to quantify the amount of copper in spots produced in the IEF and native 2D-PAGE experiments. IEF, 2D-PAGE gels, and calibration spots were read with the same phosphor screen to allow for quantitative correction for the decay of the ${ }^{64} \mathrm{Cu}$ isotope. Following alignment of the ${ }^{64} \mathrm{Cu}$ image and the original gel, the separated spots were excised, digested with trypsin, and analyzed with mass spectrometry (MS). After excision of the spots, the 2D-PAGE gel was analyzed again with a phosphor screen for one to two half-lives to confirm the efficiency of spot excision.

\section{Tandem MS analysis and protein identification}

After the radioactivity had decayed (more than ten halflives), the excised protein spots were in-gel digested with trypsin $(10 \mathrm{ng} / \mu \mathrm{l}$ in $25 \mathrm{mM}$ ammonium carbonate, $\mathrm{pH} 8.1)$ overnight at $37{ }^{\circ} \mathrm{C}$ [19]. Before digestion, proteins were reduced with $5 \mathrm{mM}$ 1,4-dithiothreitol in $25 \mathrm{mM}$ ammonium carbonate, $\mathrm{pH} 8.1$ and subsequently alkylated with $10 \mathrm{mM}$ iodoacetamide in $25 \mathrm{mM}$ ammonium carbonate, $\mathrm{pH}$ 8.1. In-gel digests were acidified with $5 \%$ formic acid and were analyzed using nano liquid chromatography (LC)-electrospray ionization (ESI)-quadrupole time of flight (QTOF) tandem MS (MS/MS). Nano-LC was performed using a nanoAcquity UPLC system (Waters, Manchester, UK) directly coupled to a QTOF Premier mass spectrometer (Waters, Manchester, UK). Peptides were delivered to a trap column packed in-house with ReproSilPur C18-AQ, $3 \mu \mathrm{m}, 120 \AA$, (Dr. Maisch, Ammerbuch, 
Germany) at flow of $4 \mu \mathrm{l} / \mathrm{min}$ in $100 \%$ solvent $\mathrm{A}(0.1 \mathrm{M}$ acetic acid in water) for $10 \mathrm{~min}$. After trapping, the trap column was switched in-line with the analytical column (Reprosil C18, 50- $\mu \mathrm{m}$ inner diameter $\times 200-\mathrm{mm}$ length, $3-\mu \mathrm{m}$ particles, packed in-house) and the flow was reduced to $150 \mathrm{nl} / \mathrm{min}$. A linear gradient from 0 to $40 \%$ solvent B $(0.1 \mathrm{M}$ acetic acid in $8: 2 \mathrm{v} / \mathrm{v}$ acetonitrile/water $)$ at $1 \% \min ^{-1}$ was used to analytically separate the content of the trap column. The column effluent was directly electrosprayed in the ESI source of the mass spectrometer using a nano-ESI emitter (New Objective, Woburn, MA, USA). The mass spectrometer was set in a data-dependent mode. Survey scans were acquired in positive ion centroid mode from $\mathrm{m} / \mathrm{z}, 400-1,500$ at a scan time of $1 \mathrm{~s}$ using an interscan time of $0.02 \mathrm{~s}$. Up to three multiply charged precursors were allowed for low energy collision induced dissociation at a selection threshold of 1,000 counts/s. MS/ MS spectra were acquired in continuous mode for $1 \mathrm{~s}$. ProteinLynx Global server 2.2.5 (Waters, Manchester, UK) was used to extract peak lists of the acquired MS/MS spectra. Proteins were identified by MS/MS ion search by using an in-house licensed Mascot 2.0 server (http:// www.matrixscience.com). Searches were done in the Swiss-Prot (Swiss-Prot 51.6) or the NCBInr (NCBInr 071207) database using the following parameters: E. coli as taxonomy restriction, trypsin as enzyme (one miscleavage allowed), peptide tolerance $15 \mathrm{ppm}$, fragment tolerance $0.05 \mathrm{Da}$, carbamidomethylated cysteine as fixed and oxidized methionine as variable modifications.

\section{Results}

\section{Method building}

From gamma counting and total copper determinations using ICP-OES, a specific activity of $2.6 \times 10^{15} \mathrm{~Bq} / \mathrm{g}$ copper was determined in the ${ }^{64} \mathrm{Cu}$ stock solution $(0.70 \pm 0.1 \mu \mathrm{M} \mathrm{Cu})$. A half-life of $12.5 \pm 0.2 \mathrm{~h}$ was found for the ${ }^{64} \mathrm{Cu}$ stock solution, which is in a good agreement with the known half-life of $12.7 \mathrm{~h}$ [20] (Fig. S1). The total copper concentration in the LB medium was $0.20 \pm 0.02 \mu \mathrm{M}$, resulting in a specific activity of $1.82 \times 10^{12} \mathrm{~Bq} / \mathrm{g}$ copper in the growth medium.

To be able to convert the intensity to DLU to radioactivity in becquerels a calibration curve was made (Fig. S2). DLU intensity represents the sum of the intensity units in all the pixels within a defined region. The regression coefficient values were between 0.992 and 0.998 , i.e., the radioactivity over DLU intensity ratio shows linearity over a considerable dynamic range of radioactivity: $10^{1}-10^{4} \mathrm{~Bq}$. A longer exposure of the phosphor screen over the paper sample containing the low dilution $(1-10$ times $){ }^{64} \mathrm{Cu}$ calibration solutions showed saturation of the screen at $2 \times 10^{9}$ DLU. The linear correlation between the DLU intensity values and radioactivity was used to quantify the amount of radioactive copper present in total in each of electrophoresis steps (i.e., transfer efficiency) and in each of the separated spots individually. To visualize the ${ }^{64} \mathrm{Cu}$ with phosphor screens the exposure time can be adapted to the amounts of radioactivity. In our study we found that an interval of 2-h exposure (after four to seven half-lives) was optimal to visualize ${ }^{64} \mathrm{Cu}$ standard solutions at all the dilution factors used.

Analysis of model recombinant cells

A recombinant strain of E. coli JM101 pUC18-azu expressing $P$. aeruginosa azurin was used to validate the four-step method of metalloproteomics. Extracted proteins (50 $\mu \mathrm{l}, 1,500 \mu \mathrm{g}$ protein) were applied by cup loading before IEF.

Figure 2 shows the autoradiography of an IEF gel of E. coli JM101 pUC18-azu. The radioactivity profile over the 24-cm IPG strip, pH 4.0-7.0, is also presented in Fig. 2. Azurin, which has a reported $\mathrm{p} I$ of 4.6 [21], exhibited an overwhelmingly high radioactivity. Nevertheless, several additional focused bands could be visualized around $\mathrm{pH}$ 6.0. The radioactivity profile for those focused bands is shown in Fig. 2. The amount of ${ }^{64} \mathrm{Cu}$ in the azurin was approximately $800-1,200$ times higher than in the endogenous soluble copper proteins from $E$. coli, which reflects the high overexpression of azurin in comparison to these endogenous proteins.

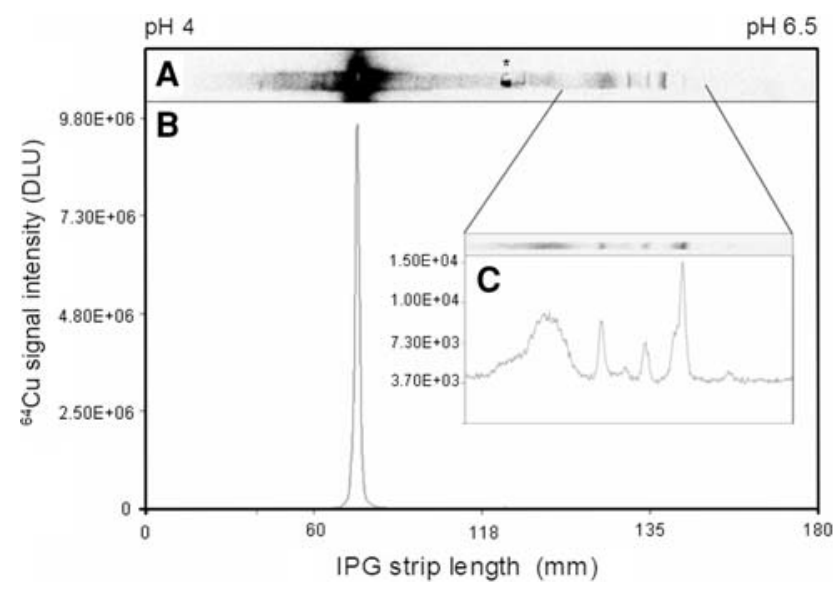

Fig. 2 Native isoelectric focusing (IEF) of azurin-producing recombinant Escherichia coli. A autoradiogram of the one-dimensional IEF gel of soluble protein extract $(1,500 \mu \mathrm{g}$ protein) obtained from the recombinant strain $E$. coli JM101 pUC18-azu. $B{ }^{64} \mathrm{Cu}$ activity profile along the immobilized $\mathrm{pH}$ gradient $(I P G)$ strip $\mathrm{pH} 4-7$. $C$ enlargement of ${ }^{64} \mathrm{Cu}$ activity around $\mathrm{pH}$ 6.0. DLU digital light units 


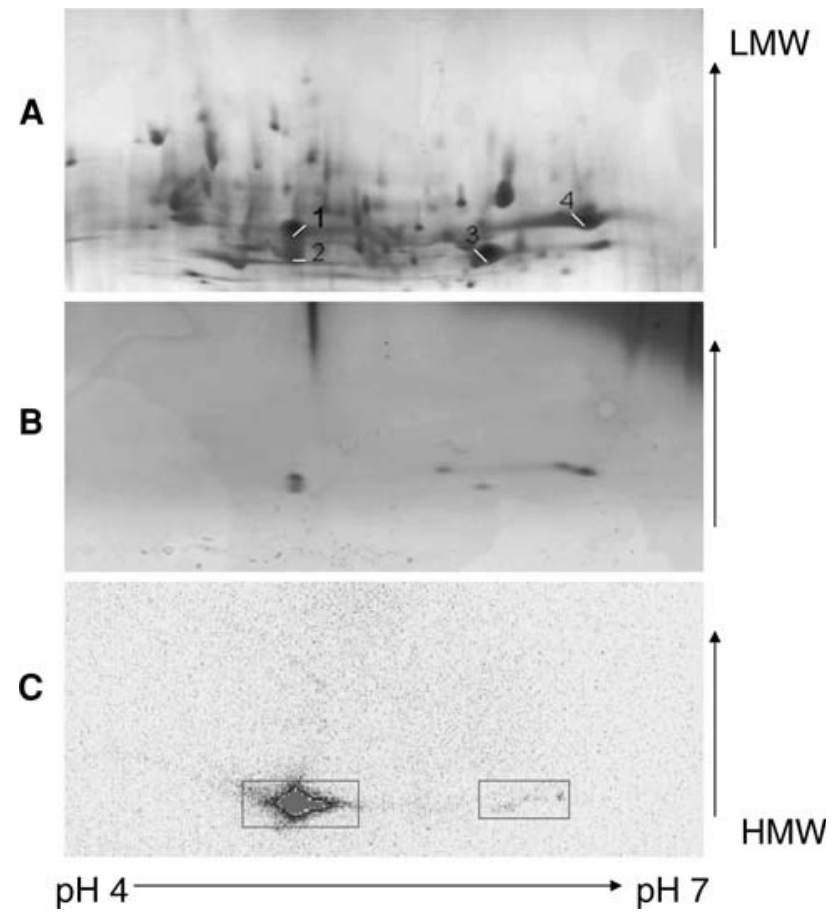

Fig. 3 Native-native 2D-PAGE of azurin-producing recombinant E. coli. A Coomassie brilliant blue (CBB) stained gel of native-native 2D-PAGE of soluble protein extract $(1,500 \mu \mathrm{g}$ protein) obtained from the recombinant strain E. coli JM101 pUC18-azu. B CBB-stained gel of the native-native 2D-PAGE of purified azurin $(0.36 \mu \mathrm{g}$ protein). $C$ autoradiogram of the native-native 2D-PAGE for $E$. coli JM101 pUC18-azu. The rectangles represent part of the gel which was used to make the 3D images in Fig. 4

Figure 3, panel A shows the CBB-stained native 2DPAGE gel of E. coli JM101 pUC18-azu. From this figure it can be seen that most of the relatively abundant proteins are separated at low $\mathrm{pH}$ between 4.5 and 6.0. The native 2D-PAGE gel of $E$. coli JM101 pUC18-azu showed several abundant spots. From MS analysis it was found that four spots contained azurin (Fig. 3, panel A). It has been reported that this azurin-overexpression strain also produces apoazurin and zinc-containing azurin [21]. To verify the presence of different azurin isoforms, pure P. aeruginosa azurin (purchased from Sigma-Aldrich) was separated with the native 2D-PAGE procedure and showed the same abundant spots as the E. coli JM101 pUC18-azu extract (see Fig. 3, panel B).

The autoradiogram of the recombinant E. coli JM101 pUC18-azu on native 2D-PAGE is shown in Fig. 3, panel C. The autoradiogram showed that only one of the expressed azurin forms incorporates copper-the 3D image is presented in Fig. 4a; the 3D image of putative copper proteins is presented in Fig. 4b. Following alignment of the phosphor screen image with the unstained native 2D-PAGE, the azurin spot was picked from the unstained gel and was analyzed with MS.

The recovery of ${ }^{64} \mathrm{Cu}$ radioactivity after the different electrophoresis steps indicates the recovery of native copper-containing proteins. The amount of radioactivity present in a 50- $\mu$ l protein sample (the required volume for use with a $24-\mathrm{cm}$ IPG strip) represents $0.1 \%$ of the initial radioactivity added at the beginning of growth. In the electrophoresis steps the $50 \mu \mathrm{l}$ of the protein sample is defined as $100 \%$ at the beginning of IEF. Applying the cup loading overnight, we found $75 \pm 5 \%$ back on the IPG strips. Between the first and the second dimension there is a $21 \pm 2 \%$ loss of protein in the equilibration solution, and $19 \pm 7 \%$ is not transferred and remains on the strip. From the initial amount added, $30 \pm 7 \%$ ended up in the $2 \mathrm{D} \mathrm{BN}$ PAGE gel. The experiment was repeated six times and in all cases showed a similar recovery of ${ }^{64} \mathrm{Cu}$ and a reproducible spot pattern on the 2D-PAGE gel.

\section{Analysis of wild-type cells}

Figure 5 shows the autoradiogram of IEF $\mathrm{pH}$ 5-7 separation of a cell-free extract from wild-type E. coli K12. The protein sample was applied at $\mathrm{pH} 4.0$ using cup loading. When the protein sample was applied at a position corresponding to a $\mathrm{pH}$ of approximately 7.0, the same welldeveloped pattern of spots around $\mathrm{pH} 6.0$ showed up, but
Fig. 4 Radioactivity profile enlargement of specific spots in native-native 2D-PAGE of azurin-producing recombinant E. coli. a Azurin. b Putative copper proteins. Note that the scales of the two graphs differ by almost 3 orders of magnitude
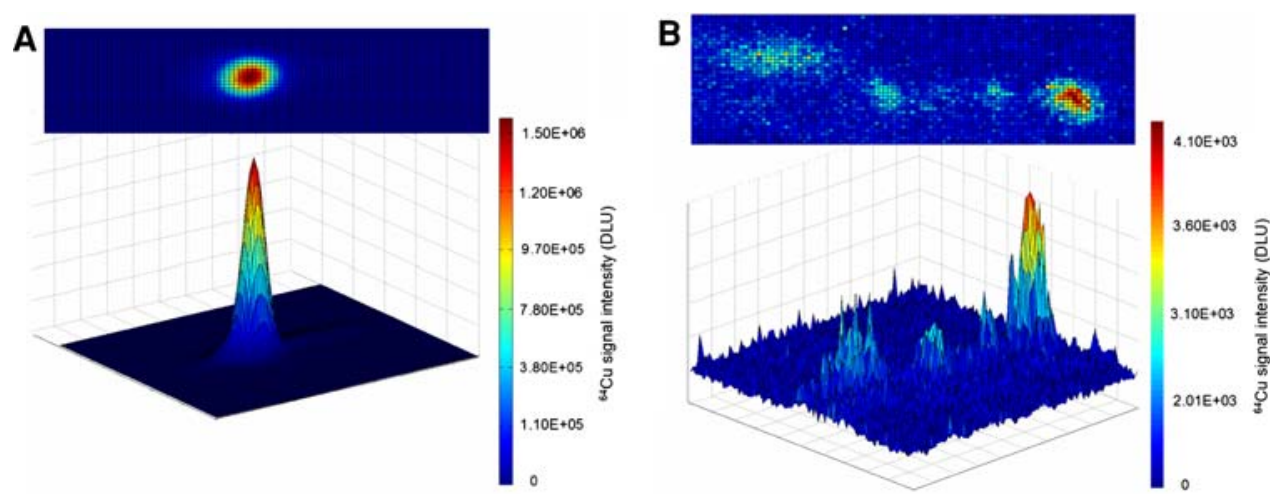


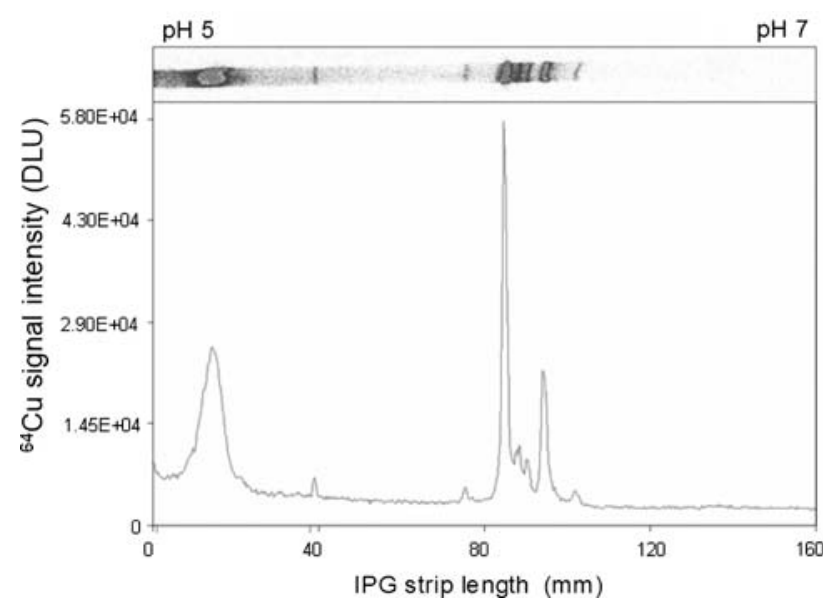

Fig. 5 Autoradiogram of 1D IEF (pH 5-7) of wild-type E. coli K12. Soluble protein extract (500 $\mu$ g protein) obtained from wild-type $E$. coli $\mathrm{K} 12$ and ${ }^{64} \mathrm{Cu}$ activity profile along the IPG strip

proteins that migrated to the $\mathrm{pH} 4.0$ region precipitated and did not focus (data not shown). In general, protein precipitation was observed to occur at the low-pH end of the IPG strip. The autoradiogram for a native 2D-PAGE gel is shown in Fig. 6a.

The high amount of radioactivity on the IEF gel at low $\mathrm{pH}$ around 5.0 (where cup loading was applied) is due to protein precipitation; therefore, this radioactivity was not
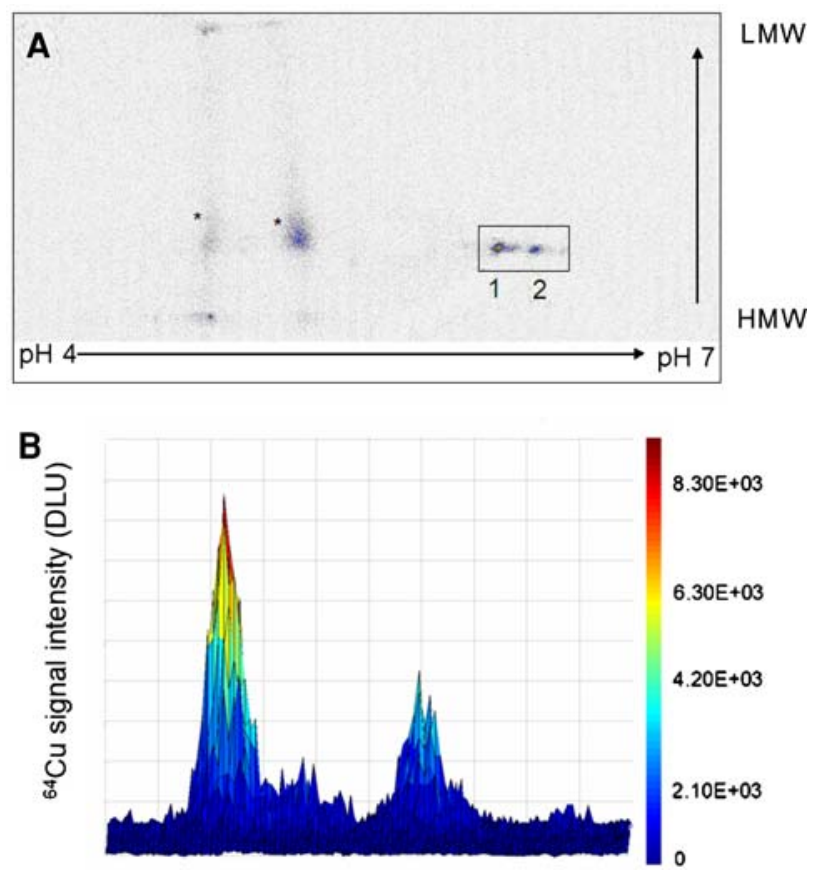

Fig. 6 Native-native 2D-PAGE of wild-type E. coli K12. a Autoradiogram of native-native 2D-PAGE of soluble protein extract (500 $\mu \mathrm{g}$ protein). The rectangle represents part of the gel used to make the 3D image. b $3 \mathrm{D}$ image of the ${ }^{64} \mathrm{Cu}$ activity in the separated spots in the $\mathrm{pH} 6.0$ region transferred to the native 2D-PAGE gel as focused spots. To better visualize the separated spot contours present around $\mathrm{pH}$ 6.0, 3D images are presented in Fig. 6b. Using the calibration curve of ${ }^{64} \mathrm{Cu}$, one can quantify the amount of copper in the individual separated spots. Spot 1 containing $0.79 \mathrm{pmol} \mathrm{Cu}$ and spot 2 containing $0.37 \mathrm{pmol} \mathrm{Cu}$ were excised from the 2D-PAGE gel and analyzed with MS. The results of the protein identification of spots 1 and 2, taken from two independent native-native 2D PAGE gels, are presented in Table 1.

Heterologously overexpressed $\mathrm{CueO}(53.3 \mathrm{kDa})$ has previously been characterized as a protein that contains four copper ions [22]. A fifth copper site has been identified in $\mathrm{CueO}$, but owing to the labile nature of this regulatory copper site [23] we assume that is not occupied after our separation procedure. On the basis of these data, we can calculate the amount of the protein present in separated spots. In spot 1 the amount of protein present after 2D-PAGE separation is $10.5 \mathrm{ng}(0.20 \mathrm{pmol} \mathrm{CueO})$, which represents only $0.007 \%$ of the total protein estimated to be present in the 2D gel. This amount of protein is in the detection range of practical MS.

The proteins identified in spot 2 (SurA, FliC, and OppA, see Table 1) have been well characterized and are not known to contain copper, so it is possible that the protein(s) responsible for the copper in spot 2 is below the detection range of the MS and remains to be identified.

In the present case the recovery of ${ }^{64} \mathrm{Cu}$ after the electrophoresis steps is comparable to that in the experiment on the strain carrying the azurin gene described above, the only difference being that the amount of radioactivity in the wild-type cell-free extracts is 10 times lower $(0.01 \%$ from the initial radioactivity added for growth) owing to the absence of highly abundant azurin.

\section{Discussion}

2D-PAGE is a key technique in the field of proteomics. In particular IEF/SDS-PAGE and BN/SDS-PAGE are widely used for protein separation from complex mixtures. The main advantage of these techniques is in their high separation potential. Unfortunately, in the separation process the proteins are often denatured into their subunits and, in general, activity is lost irreversibly. Recently, a new native 2D-PAGE separation technique has been developed: BN/BN-PAGE. This method retains protein activity on the gel, however at the expense of a very low separation resolution $[15,16]$.

In the present work we described the separation of a complex protein mixture while keeping the proteins in their native state using a new combination and adjustment of existing techniques, namely, native IEF/BN-PAGE, 
Table 1 Protein identification after native-native 2D polyacrylamide gel electrophoresis separation of Eschericia coli K12 soluble protein extract

\begin{tabular}{|c|c|c|c|c|c|}
\hline Spot & Accession & Protein & Mass (Da) & $\begin{array}{l}\text { No. of unique } \\
\text { peptides }\end{array}$ & $\begin{array}{l}\text { Mascot } \\
\text { protein score }\end{array}$ \\
\hline \multirow[t]{2}{*}{ Spot $1 /$ gel 1} & CUEO_ECOLI & Multicopper oxidase $\mathrm{CueO}$ & 56,690 & 2 & 82 \\
\hline & OPPA_ECOLI & Oligopeptide binding protein $O p p A^{a}$ & 60,975 & 1 & 44 \\
\hline Spot $1 /$ gel 2 & CUEO_ECOLI & Multicopper oxidase $\mathrm{CueO}$ & 56,690 & 1 & 70 \\
\hline \multirow[t]{3}{*}{ Spot 2/gel 1} & SURA_ECOLI & Prolyl isomerase/chaperone $\operatorname{SurA}^{\mathrm{a}}$ & 47,254 & 13 & 474 \\
\hline & FLIC_ECOLI & Flagellin FliC ${ }^{\mathrm{a}}$ & 51,265 & 6 & 241 \\
\hline & OPPA_ECOLI & Oligopeptide binding protein OppA ${ }^{\mathrm{a}}$ & 60,975 & 5 & 224 \\
\hline Spot 2/gel 2 & FLIC_ECOLI & Flagellin FliC ${ }^{\mathrm{a}}$ & 51,265 & 5 & 227 \\
\hline
\end{tabular}

The position of spots 1 and 2 is indicated in Fig. 6a. Proteins were identified after trypsin digestion and tandem mass spectrometry analysis by tandem mass spectrometry ion search using Mascot with $E$. coli taxonomy restriction

${ }^{a}$ OppA, SurA, and FliC are not known or expected to be copper proteins, but they apparently overlap with an unidentified copper protein

short-lived tracer radioisotopes, and MS/MS. With this combination of techniques, metalloproteins are found to be detectable on gel (based on the presence of a radioisotope) with a separation resolution of native proteins that is significantly higher than in previously described native separation techniques. The combination of the IEF/BNPAGE with radioisotopes shows that the proteins retain their metal cofactor (and, by implication, their native structure) during and after the separation process.

\section{Metalloproteomics techniques}

With the present approach (IEF/BN-PAGE in combination with radionuclides), it is straightforward to quantify the amount of metal present in a separated spot, and to estimate the amount of the target protein. Relative to other nonnative protein detection methods, the present method has a high sensitivity and can detect amounts of metalloproteins in the lower femtomolar range. Non-autoradiographybased analytical techniques for metal determination in protein samples, including ICP-OES and electroanalytical methods, generally exhibit poorer sensitivity. In our view the approach presented here is perfectly complementary to metalloproteomics methods that have recently emerged. These recently reported methods are laser-ablation ICP-MS, high-throughput X-ray absorption spectroscopy, a high-throughput colorimetric/luminometric method, and a 2D-LC ICP-MS based method [3, 24, 25]. The first technique can be applied to a biological tissue directly and can be used to detect multiple different metals simultaneously. However, it has the disadvantage of being destructive to the biological sample, and has a detection limit in the micromolar range for copper and zinc. The high-throughput X-ray absorption spectroscopy method is, essentially, noninvasive to the protein sample. However, it is only applicable to isolated pure proteins of high concentration. The third method, which uses a combination of two luminometric assays and one colorimetric assay to detect a range of metal ions, has the advantage of being inexpensive and straightforward; however, it is only qualitative and is 1,000 -fold less sensitive than the method presented here. Furthermore, since the identification of the metal ions in the colorimetric/luminometric method relies on an ingenious combination of positive and negative results in the different assays, mixtures of metal ions will be difficult to analyze. The 2D-LC ICP-MS method is based on protein separation using 2D-LC, metal detection by ICP-MS, and by carefully aligning the metal distribution with the distribution of proteins after SDS-PAGE by principal component analysis. The advantage of this method is that multiple different metals can be analyzed simultaneously and considerable flexibility in the separation is possible by changing LC techniques. The 2D-LC approach generates a large number of samples that have to be analyzed by ICPMS and SDS-PAGE, while the native-native 2D-PAGE method allows visualization of all proteins that contain a specific metal simultaneously. Furthermore, the sensitivity of ICP-MS will only allow detection of relatively abundant metalloproteins. In our view the newly reported method and the 2D-LC method are perfectly complementary in respect to sensitivity, scope, and throughput.

An additional advantage of the technique described here is the wide dynamic range of radioactivity that is detectable, allowing both highly abundant (e.g., azurin) and lowabundance proteins (e.g., $\mathrm{CueO}$ ) to be seen in the same gel. Moreover, all of these proteins can be analyzed with independent techniques after the decay of the radioactivity. Furthermore, in addition to its high reproducibility, the present generic method promises to be broadly applicable to metalloproteins in general, at least for those with "producible" radionuclides of suitable halt-life and specific activity. A number of very promising options for biometals are listed in Table 2. The resolution of the present native 2D-PAGE approach can possibly be further 
improved by the implementation of narrow-pH-range IPG strips and/or by fractionation of the crude cell extract before application to the 2D-PAGE gel. Quantitation of the amount of protein that is transferred from the IEF IPG strip to the 2D BN-PAGE gel based on radioactivity showed that approximately $30 \%$ is recovered on the native $2 \mathrm{D}-\mathrm{PAGE}$ gel. Aggregation, oxidation, and precipitation most probably are among the processes which limit protein transfer during these electrophoresis steps [26].

Finally, the native 2D-PAGE technique offers a unique opportunity to study metal trafficking into and out of specific proteins, which is not possible with any of the previously described metalloproteomics techniques. By addition of a pulse of radioactive metal isotope to a steadystate culture, incorporation of that metal ion into specific metalloproteins can be visualized and quantified. We foresee that this method may prove to be powerful in unraveling metal trafficking pathways when applied to mutants of specific cofactor biosynthetic pathways or under a variety of environmental conditions.

\section{Copper-containing proteins in E. coli}

MS analysis identified the multicopper oxidase CueO, which is a periplasmic soluble protein, as part of a copper efflux system responsible for the oxidation of $\mathrm{Cu}^{+}$to $\mathrm{Cu}^{2+}$ [27]. In previous biochemical studies it was only possible to positively identify the protein as a copper protein after homologous overexpression in E. coli [28]. The present work for the first time detected $\mathrm{CueO}$ as a copper protein in a natural wild-type $E$. coli background. In addition to metalloprotein identification, our method also allows for quantification of the protein: the native $\mathrm{CueO}$ expression level was calculated, taking the recovery during the separation procedure into account, to be $0.007 \%$ of total soluble protein $(0.7 \mathrm{pmol}$ in $500 \mu \mathrm{g}$ protein extract). Our data therefore suggest that $\mathrm{CueO}$ is naturally involved in the detoxification of $\mathrm{Cu}^{+}$by wild-type E. coli. An excess of

Table 2 Metal radioisotopes with potential for metalloproteomics

\begin{tabular}{ll}
\hline Radionuclide & Half-life (h) \\
\hline${ }^{56} \mathrm{Mn}$ & 2.6 \\
${ }^{65} \mathrm{Ni}$ & 2.5 \\
${ }^{64} \mathrm{Cu}$ & 12.7 \\
${ }^{67} \mathrm{Cu}$ & 61.8 \\
${ }^{69} \mathrm{Zn}$ & 13.8 \\
${ }^{99} \mathrm{Mo}$ & 66 \\
${ }^{187} \mathrm{~W}$ & 23.8 \\
\hline
\end{tabular}

The selection criteria are $t_{1 / 2}$ between 2 and $100 \mathrm{~h}$, suitable $\beta^{-}$ abundance, and energy
$\mathrm{Cu}^{+}$generates potentially harmful reactive oxygen species, which causes oxidative stress.

Other proteins in E. coli that are expected to contain copper are the $\mathrm{Cu}(\mathrm{I})$ efflux system CusCFBA, the CusCBA part of which spans both the inner and the outer membrane, with CusF being a soluble periplasmic protein; the $\mathrm{Cu}(\mathrm{I})$ pump CopA that translocates copper from the cytoplasm to the periplasm; cytochrome $c$ oxidase Cyt bo3; NADH dehydrogenase NDH-2; aromatic amine oxidase MaoA; the CuZn SOD SodC; and the copper-responsive regulators CueR and CusR. CusCBA, CopA, Cyt bo3, and NDH-2 are membrane proteins and are not solubilized during the protein sample preparation. MaoA is soluble but is only produced when $E$. coli is grown on aromatic amines, e.g., 2-phenylethylamine, as the sole carbon source [29]. An additional plasmid-borne copper-resistance system PcoABCDE is located on the plasmid pRJ1004; however, this is only present in certain $E$. coli strains that live in copper-rich environments. The plasmid pRJ1004 is not present in the strains used here. CusR is involved in regulating copper tolerance in E. coli grown under anaerobic conditions and aerobically only under extreme copper stress (copper concentration exceeding $100 \mu \mathrm{M}$ ), and was therefore not expected to be detectable in this study [30]. This would mean that, in addition to $\mathrm{CueO}$, the complete list of known soluble copper-containing proteins in E. coli only contains CusF, SodC, and CueR.

CusF is a periplasmic copper binding protein that specifically binds $\mathrm{Cu}(\mathrm{I})$, however with a relatively poor $K_{\mathrm{D}}$ of $0.5 \mu \mathrm{M}$ and with no affinity for $\mathrm{Cu}$ (II) [31]. The total amount of $\mathrm{Cu}(\mathrm{II})$ in the $\mathrm{LB}$ growth medium was $0.2 \mu \mathrm{M}$, so even under the extremely unlikely scenario that in the aerobically grown E. coli all copper would have been converted to $\mathrm{Cu}(\mathrm{I}), \mathrm{CusF}$ would have been loaded only for $40 \%$, and this number would have rapidly dropped in the diluting cell-breakage procedure.

The copper-containing SOD SodC is induced late in the growth cycle of $E$. coli and is important for the culture in the stationary phase. Only in mutants lacking SodA and SodB (iron and manganese SODs) is the enzyme important for growth under aerobic conditions. Furthermore, it is known that E. coli SodC can release its metals easily [32]: it is very sensitive to proteolytic degradation, making the enzyme very unstable in crude preparations even though it is stable in pure form [33]. SodC has only been isolated from E. coli strains lacking the SodA and SodB genes.

Interestingly, the copper-responsive regulator CueR was not detected in this study. This may seem surprising since CueR is known to have high affinity for $\mathrm{Cu}(\mathrm{I})$, and has even been reported to sense $\mathrm{Cu}(\mathrm{I})$ in the zeptomolar $\left(10^{-21} \mathrm{M}\right)$ range [34]. Although CueR regulates copper tolerance in E. coli under aerobic conditions, and was therefore expected to be present in our experiments, it is highly 
selective for $\mathrm{Cu}(\mathrm{I})$ over $\mathrm{Cu}(\mathrm{II})$. We assume that by action of $\mathrm{CueO}$ most $\mathrm{Cu}$ (I) has been oxidized and, therefore, that the amount of $\mathrm{Cu}(\mathrm{I})$ bound to CueR falls below the detection limit.

We conclude that, other than $\mathrm{CueO}$, wild-type E. coli K12 does not express any soluble copper-containing proteins above an expression level of approximately $0.003 \%$ of total protein.

The native-native 2D-PAGE procedure reported here is in principle applicable to metalloproteomics of any metal ion in any biological system. Several promising combinations of metals and cell types are presently being explored in our laboratory.

Acknowledgments We thank A. Tepper (Leiden University, The Netherlands) for supplying the azurin-producing E. coli strain. We thank J.J. Kroon (Department of Radiation, Radionuclides and Reactors, Delft University of Technology, The Netherlands) for help with the radioisotope ${ }^{64} \mathrm{Cu}$ preparation. This research was supported by grant CW-NWO 700.55.004 from the Council for Chemical Science of the Netherlands Organization for Scientific Research. PV and MP acknowledge financial support from the Netherlands Proteomics Centre and the Kluyver Centre for Genomics of Industrial Fermentation.

Open Access This article is distributed under the terms of the Creative Commons Attribution Noncommercial License which permits any noncommercial use, distribution, and reproduction in any medium, provided the original author(s) and source are credited.

\section{References}

1. Bartnikas TB, Gitlin JD (2001) Nat Struct Biol 8:733-734

2. Rensing C, Grass G (2003) FEMS Microbiol Rev 27:197-213

3. Tottey S, Waldron KJ, Firbank SJ, Reale B, Bessant C, Sato K, Cheek TR, Gray J, Banfield MJ, Dennison C, Robinson NJ (2008) Nature 455:1138-1142

4. Finney LA, O'Halloran TV (2003) Science 300:931-936

5. Schägger H, von Jagow G (1991) Anal Biochem 199:223-231

6. Wittig I, Braun HP, Schägger H (2006) Nat Protoc 1:418-428

7. Niepmann M, Zheng J (2006) Electrophoresis 27:3949-3951

8. Bodzon-Kulakowska A, Bierczynska-Krysik A, Dylag T, Drabik A, Suder P, Noga M, Jarzebinska J, Silberring J (2007) J Chromatogr B Anal Technol Biomed Life Sci 849:1-31
9. Oliva A, Farina JB, Llabrés M (2007) Curr Pharm Anal 3:230248

10. Hooker BS, Bigelow DJ, Lin CT (2007) Biochem Biophys Res Commun 363:457-461

11. Zheng C, Ma G, Su Z (2007) Electrophoresis 28:2801-2807

12. Braun RJ, Kinkl N, Beer M, Ueffing M (2007) Anal Bioanal Chem 389:1033-1045

13. Bose M, Adams BP, Whittal RM, Bose HS (2008) Electrophoresis 29:753-760

14. Schägger H, Pfeiffer K (2000) EMBO J 19:1777-1783

15. Eubel H, Heinemeyer J, Sunderhaus S, Braun HP (2004) Plant Physiol Biochem 42:937-942

16. Sunderhaus S, Eubel H, Braun HP (2007) Methods Mol Biol 372:315-324

17. Van de Kamp M, Hali FC, Rosato N, Agro AF, Canters GW (1990) Biochim Biophys Acta 1019:283-292

18. Van Elteren JT, Kroon KJ, Woroniecka UD, De Goeij JJM (1999) Appl Radiat Isot 51:15-19

19. Wilm M, Schevchenko A, Houthaeve T, Breit S, Schweigerer L, Fotsis T, Mann M (1996) Nature 379:466-469

20. Abbas K, Kozempel J, Bonardi M, Groppi F, Alfarano A, Holzwarth U, Simonelli G, Hofman H, Horstmann W, Menapace E, Leseticky L, Gibson N (2006) Appl Radiat Isot 64:1001-1005

21. Nar H, Huber R, Messerschmidt A, Filippou AC, Barth M, Jaquinod M, Van de Kamp M, Canters GW (1992) Eur J Biochem 205:1123-1129

22. Roberts SA, Weichsel A, Grass G, Thakali K, Hazzard JT, Tollin G, Rensing C, Montfort WR (2002) Proc Natl Acad Sci 99:26662771

23. Roberts SA, Wildner GF, Grass G, Weichsel A, Ambrus A, Rensing C, Montfort WR (2003) J Biol Chem 278:31958-31963

24. Lobinski R, Moulin C, Ortega R (2006) Biochimie 88:1591-1604

25. Högbom M, Ericsson UB, Lam R, Bakali MA, Kuznetsova HE, Nordlund P, Zamble DB (2005) Mol Cell Proteomics 4:827-834

26. McDonough J, Marbán E (2005) Proteomics 5:2892-2895

27. Kataoka K, Komori H, Ueki Y, Konno Y, Kamitaka Y, Kurose S, Tsujimura S, Higuchi Y, Kano K, Seo D, Sakurai T (2007) J Mol Biol 373:141-152

28. Grass G, Rensing C (2001) Biochem Biophys Res Commun 286:902-908

29. Cooper RA, Knowles PF, Brown DE, McGuirl ME, Dooley DM (1992) Biochem J 288:337-340

30. Outten FW, Huffman DL, Hale JA, O'Halloran TV (2001) J Biol Chem 276:30670-30677

31. Kittleson JT, Loftin IR, Hausrath AC, Engelhardt KP, Rensing C, McEvoy MM (2006) Biochemistry 45:11096-11102

32. Benov L, Sage H, Fridovich I (1997) Arch Biochem Biophys 340:305-310

33. Battistoni A, Rotilio G (1995) FEBS Lett 374:199-202

34. Changela A, Chen K, Xue Y, Holschen J, Outten CE, O'Halloran TV, Mondragón A (2003) Science 301:13831387 